\title{
Origen Of Alexandria
}

\author{
Vivian Arsanious
}

\begin{abstract}
Origen of Alexandria was an early Christian theologian who stands out as an anomaly amongst Church Fathers. He is considered to have entertained heretical views, yet is still held in high esteem by the Church today. The church Fathers were theologians whose writings and debates helped forge an approach for articulating the doctrines of Christianity. Why should Origen stand among these esteemed figures? Why should a heretic hold such acclaimed standing in the heart of the Church?
\end{abstract}

\section{Introduction}

Origen of Alexandria is not just respected by the Church, but often extolled. His writings continue to be perused with reverence by Church leaders, and for centuries, his style of interpretation was imitated and indeed could not be avoided by those who studied Scripture. Why then, one must ask, is this favor shown to him? This paper will first examine the influences surrounding Origen as he grew. It will also discuss major events in Origen's life, such as his move from secular learning to religious learning, his self-castration, and his vital meeting with Ambrose which would change the course of his entire life. I will then survey the persecutions which followed him from that point on, ending in a discussion on Origen's view of martyrdom, an ideology that would have immense reverberations in the Church and false doctrines that were attributed to him.

Origen's commentaries on Scripture are not only the most numerous, but his style of interpretation was unique amidst existing scholarship. Many early Christians found gnosticism alluring because of its promise of a secret, higher knowledge. Origen's commentaries showed that Scripture contained a knowledge of God beyond the simple meaning, and unlike gnosticism which was a set of beliefs that mixed Greek philosophy with Christian ideas, one that was consistent with the image preached by the apostles. This understanding, along with something innate about his character, would attract generations of Christians to him for centuries to come. Origen's name would forever be intertwined with this particular style of interpretation, and thus he would never loose the complete respect of Christians, even if some of his ideas were to be considered discontinuous from the teachings of the apostles, or in other words, heretical.

Sources that currently exist relating to the life and beliefs of Origen are indeed numerous in comparison to other men from antiquity, but like others from the same period, they provide us with much less information than we would like to know. Our primary sources range from homilies given by Origen to letters he wrote and commentaries on Scripture, though in some cases only translations of his works have survived. Other sources include Eusebius' ecclesiastical history, in which most of the sixth book is devoted to Origen. The account given by Eusebius is usually handled with care by scholars, because of his bias toward Origen and his attempts to defend him from accusations of heresy. 


\section{Who was Origen?}

While we cannot be completely certain of the exact date, it can be said with a certain amount of confidence that Origen of Alexandria was born in the year 185 A.D. to Christian parents. ${ }^{1}$ He was born in Alexandria, the second largest city in the Roman Empire, which by that time had become a multicultural center due to its commercial prowess and prime location in the Roman World. Despite the presence of several ethnicities in the area, distinctions between nationalities remained very pronounced. $^{2}$ This implies that just because someone was born in Alexandria, it did not automatically make them Egyptian. To which race then, did Origen belong?

Heine states that it is likely that Origen was of Greek decent, despite Eusebius' claim that he was Egyptian. He makes this argument based on Origen's education, privileges, and connections. Origen received a Greek education and it is widely believed that he took up his father's profession as a grammatikos, an educator, for at least some portion of his life. Heine then reminds his readers that educational institutions were class specific, and thus it would be unlikely that an Egyptian would be allowed to study there. ${ }^{3}$ On the other hand, Heisey argues that Origen was likely an Egyptian, her argument substantiated by Origen's own statement in his Commentary on John. ${ }^{4}$ Additionally, McGukin believes that Origen was born from a mixed marriage. He takes into account Origen's Greek education, as well as his thoroughly populist Egyptian name, which means 'Child of Horus'.

McGukin's argument appears to be the most accurate. Heine states that religion was such a problematic point of tension between Greeks and Egyptians, that Ptolemy felt it necessary to create a new deity in an attempt to bring the two races together, at least in religion. The attempt was a catastrophic failure, resulting only in increased tensions between the two groups. ${ }^{5}$ It is unlikely in this environment that a Greek family, Christian or otherwise, would choose to adopt the name of the other groups' god, unless they had a legitimate reason to. In the Roman Empire at the time, citizenship of a city was only extended to Greeks. The Egyptians did not possess the same privileges. By these terms, a child of a mixed marriage would be denied the rights of citizen. However, if one had a Greek educated parent, no one could stop the parent from having the child educated regardless of what their ethnic background was. ${ }^{6}$ McGukin's belief that Origen came from a mixed marriage between a Greek and an Egyptian fits nicely into what we know about Origen. Eusebius told readers that he encouraging many of his students to martyrdom by accompanying them. Scholars have often wondered what kept Origen himself from being targeted. Evidence exists that some persecutions targeted only citizens who were Christians. ${ }^{7}$ If Origen was not a Greek Citizen, then his presence at his students' martyrdoms would make much more sense.

\section{Origen's Alexandria}

The Alexandria of the ancient world was renowned as an intellectual Mecca. Scholars from across the ancient world came to take up residence in Alexandria, transforming it into a place where students flocked in search of a good teacher. Its reputation as an intellectual center was not due only to the famous teachers that inhabited the city, but also due to the wide array of books which filled

\footnotetext{
${ }_{1}^{1}$ John A. McGukin, The Westminster handbook to Origen (Louisville, Ky. : Westminster John Knox Press, 2004$), 2$.

${ }^{2}$ Ronald E. Heine, Origen: Scholarship in the service of the Church (Oxford : Oxford University Press, 2010), 4-5.

${ }^{3}$ Ibid., 20.

${ }^{4}$ Nancy R. Heisey, Origen, the Egyptian : a literary and historical consideration of the Egyptian background in Origen's writings on martyrdom (Nairobi, Kenya. Paulines Publications Africa, 2000), 29.

${ }^{5}$ Heine, Origen: Scholarship in the service of the Church, 10-11.

${ }^{6}$ McGukin, The Westminster handbook to Origen, 3-4.

7 Ibid., 3.
} 
Alexandria's libraries, and whose trickle-down effect impacted even those in the lowliest positions. ${ }^{8}$ A notable feature of Alexandria's academic life was the Museum-Library, which acted like a mix between a modern state-funded educational institution and an ancient version of a think-tank. It did not, however, take students on and educate them, for the focus was much more on research and preservation of ancient texts. ${ }^{9}$ The intellectual side of Alexandria would have a long lasting effect on the young Origen. He developed an acute attention to detail and was imprinted with the marks of Alexandrian literary scholarship. Growing up in a society where writing commentaries on ancient text was commonplace, I argue that it was natural for him to extend such thinking to Scripture.

The bookish side of Alexandria was not the only element that greatly shaped the direction of Origen's life. The second was his strong Christian background. Origen came from a devoutly religious family. His father, Leonidas, insisted that his son study Scripture alongside the normal education of the Greeks. Evidence suggests that Leonidas was a teacher — a grammatikos, and it is likely that he had a hand in his son's education. Eusebius noted an instance where Leonidas expressed surprise at the questions that came from Origen, which he himself could hardly answer. ${ }^{10}$ When Origen was sixteen, his father died under a persecution which was orchestrated by Septimius Severus against those who professed the Christian faith. Origen thought nothing of joining his father, but was prevented by his mother. This shows us that a deep-seated dedication to Christ and the Christian faith had developed in Origen, just as his father had intended. According to Nautin, Leonidas' martyrdom would only strengthen his son's ties to the Church. ${ }^{11}$

\section{Scholarly development}

The years following his father's death were crucial in forming the Origen we are familiar with today. Origen's benefactor, who took him in after his father's death, also provided accommodation for a certain Paul of Antioch, whom Origen would characterize as a heretic. ${ }^{12}$ It is impossible to know whether this was Origen's first experience with gnosticism. However, it is logical to assume that he owes at least some of his intimate knowledge of gnosticism to this period of his life. The value of this knowledge would not become evident until Origen's later years, when he devoted himself solely to the Gospel, and turned his efforts to writing against gnosticism. During this particular period however, his focus was not on Scripture, but rather on secular learning as a means to support his family. Although seemingly irrelevant to Origen's development as an ancient Christian apologist, his time in secular studies would actually become instrumental to his skills as a biblical commentator because it was during this period that he personalized the common method used by Hellenistic grammarians for approaching a literary text. ${ }^{13}$ Heines tells us that the texts were often treated in four stages: "(1) Criticism to determine what the ancient author had written; (2) Reading and recitation which included memorizing the text for recitation; (3) Explanation of the text; [...] (4) Judgment, or the moral teaching of the text." 14 The details of this method would later enhance Origen's biblical commenting ability.

Origen's split with secular education began when students approached him desiring to hear the word of God. At the time, Christian teachers were in low supply in the city, as news of an impending

\footnotetext{
${ }^{8}$ Heine, Origen: Scholarship in the service of the Church, 22.

${ }^{9}$ Ibid., 13-14.

${ }^{10}$ McGukin, The Westminster handbook to Origen, 4.

${ }^{11}$ Nautin, 414.

${ }^{12}$ Joseph W. Trigg, Origen (London, Routledge, 1998), 7.

${ }^{13}$ Ibid., 5.

${ }^{14}$ Heine, Origen: Scholarship in the service of the church, 61,
} 
persecution directed against Christian teachers had caused many of them to flee Alexandria. ${ }^{15}$ Although Origen specialized in Greek education, he was a known Christian. Since he was one of the few teachers prepared to teach about Christianity that remained in Alexandria, he was sought out. He "soon became so busy with his Christian instruction that he gave up his secular teaching" and would eventually sell much of the Greek literature classics he had collected in order to support himself. ${ }^{16}$ The Bishop of the Alexandrian Church, Demetrius, soon took an interest in this increasingly popular teenager. The low supply of Christian teachers, coupled with the fact that he was the son of a noteworthy martyr, and an all-around enthusiastic young Christian, encouraged Demetrius to appoint Origen as the Principal of the Catechetical School of Alexandria.

When Origen successfully became the head of the School of Alexandria at the age of eighteen, he adopted a rigorously ascetic lifestyle.

He lived precariously. He drank no wine, walked barefoot and slept on the floor. Almost his chief expenditure was for midnight oil: he had a habit, which lasted throughout his life, of writing and studying at night. ${ }^{17}$

He believed that his primary task was the "exposition of Scripture", and he composed vast numbers of commentaries and sermons in line with that belief. ${ }^{18}$ This ceaseless writing earned Origen the nickname 'Adamantius.' Payne believes that this was because no one before him had wrestled with the inner meanings of Christianity "with such formidable energy." 19

Many scholars have devoted much of their time seeking to understand the importance of the School of Alexandria to the actual city. Was it simply another school, on par with the gnostic schools prevalent in the area, or was it something special? Eusebius seems to imply that the school was indeed unique, but that does not deter many modern scholars, most notably Heine and McGukin, from disagreeing with him. On the other hand, Robert Payne sees Origen as Clement's student, and thus, the natural successor to School of Alexandria, thus distinguishing it. ${ }^{20}$ The city of Alexandria had several schools that were started by individual teachers. A teacher would take on a couple of students and teach them his philosophy for as long as they wished to study under him, and that was the extent of an individual's school. ${ }^{21}$ Origen started out this way. A group of students approached him, and he agreed to teach them about Christianity. Eusebuis implies a change in Origen's scholarly status when he was appointed to the school of Alexandria. Even though some do not consider the school a prestigious institution, it consisted of more than just one teacher relaying his ideas to a couple of students. Origen's job was to prepare catechumens for baptism, a task which he surely took very seriously.

Church hierarchy and structure was established very early in Christian history. The Romans recognized and persecuted the orthodox Christians, because these were the Christians so insistent upon their faith that they were prepared to die for it. This recognition would have given orthodox Christians a place above the gnostics of the era, for they were the group that marched bravely to their deaths under the eyes of citizens of the empire. The Catechetical school of the orthodox would surely have enjoyed a distinction based on its association with these people.

\footnotetext{
15 Ibid., 61.

${ }^{16}$ Heisey, Origen the Egyptian, 11.

${ }^{17}$ Robert Payne, The holy fire: the story of the Fathers of the Eastern Church (London: Skeffington, 1958), 45.

${ }^{18}$ Henry Chadwick, The Early Church (London: Penguin Books, 1967), 109

19 Payne, The boly fire, 43.

${ }^{20}$ Ibid., 44

${ }^{21}$ Heine, Origen: Scholarship in the service of the church, 51.
} 


\section{Castration: Fact or Fiction?}

However devoted Origen may have been, he nonetheless retained a youthful impulsiveness. Eusebius tells of what could be considered one of history's greatest ironies. The man whose name would forever become associated with allegorical interpretation took literally a verse in Scripture that the Church had traditionally understood allegorically. ${ }^{22}$ Origen literally applied to himself the statement in Matthew's Gospel, "There are those who have made themselves eunuchs for the sake of the kingdom of heaven," and castrate himself. ${ }^{23}$ However, Chadwick is one modern scholar who disputes this. He takes Origen's criticism of the very verse that refers to people who make themselves eunuchs for the kingdom of God, as evidence not of remorse, but to indicate that he never committed the act. He argues that it is likely that "Eusebius was uncritically reporting malicious gossip retailed by Origen's enemies." ${ }^{24}$

I argue that the alternative, that Origen really did castrate himself, is more likely for two reasons. First, Eusebius attempted to justify the act, meaning that if he could have found any evidence of Origen denying the charge, he would have jumped at the chance to denounce the bishop Demetrius as a diabolical, vicious liar. When Demetrius found out about this head-strong act, he wasted no time in condemning it. The second reason is that Eusebius had access to hundreds of Origen's letters, a luxury we do not hold. If this 'rumor' was as widespread as Chadwick suggests, then it is not unlikely that someone questioned Origen about it directly. Eusebius gives two justifications for Origen's action, the first being that it was a 'sin of youth.' The second subsisting that he intended to "eliminate every pretext for shameful calumny on the part of unbelievers, he was led to carry out literally the Savior's word." "25 The fact that Eusebius also tells us that Origen did his best to conceal what he had done boasts of an alternate motive. His self-castration was likely an act that he believed would allow him to teach the Gospel without fear of falling into sexual immorality. Students, both young men and women, flocked to hear him speak. Cribiore, in her exploration of Greek education in Hellenistic and Roman Egypt notes that it was more common for women to have a primary education but much less common, though not unheard of, even among the upper classes, for them to have a secondary education. ${ }^{26}$ Origen is known to have had many female students, amongst whom several were martyred. ${ }^{27}$

Believing this, Origen's ascestism was impressive, even if at times it was somewhat naïve. He demanded from himself the highest forms of purity and held to those principles. This persistent attitude, among other things, was one that was picked up and adopted into early Christian monasticism. However, Origen did not encourage others to follow his chosen way of living. Among his contemporaries were a certain group of gnostics who made the claim that the Paraclete had forbidden marriage and ordained fasting. ${ }^{28}$ Origen was very critical of this movement. He did not feel that it was right to impose acute asceticism on people, because not everyone could benefit from

\footnotetext{
${ }^{22}$ Henri Crouzel, Origen (Edinburgh: T. \& T. Clark, 1989), 9.

${ }^{23}$ Matthew 19:12, NKJV.

${ }^{24}$ Chadwick, The Early Church, 109.

25 Crouzel, Origen, 9.

26 Raffaella Cribiore, Gymnastics of the Mind:Greek Education in Hellenistic and Roman Egypt (Princeton, N.J.: Princeton University Press, 2005), 74-5.

${ }^{27}$ Eusebius, Kirsopp Lake, John Ernest Leonard Oulton, and Hugh Jackson Lawlor, The ecclesiastical bistory (London: W. Heinemann, 1926), 23.

${ }^{28}$ Heine, Origen: Scholarship in the service of the church, 141.
} 
it. Christian monasticism, which also started in Egypt, consisted of young men who had chosen to live their lives under a rule of strict asceticism, as Origen had, but also felt that this lifestyle was not for everyone.

\section{The Lifelong Learner}

Eventually, the storm that accompanied Origen's castration dissipated and his following grew, to the extent that Origen found it necessary to divide students. He left the instruction of beginning Christians to his student Heraclas, who later succeeded Demetrius as Bishop of Alexandria. Origen then dedicated himself to the instruction of the more advanced students. ${ }^{29} \mathrm{He}$ began attending lectures of Greek Philosophers with the intent to employ secular education in communicating his Christian message. Origen saw Greek philosophy as a means to an end. Unlike Clement, who attributed a certain authority to Greek philosophies such as platonism, Origen's view of them was much more condescending. His regard for Greek literary work is even lower, as he "criticizes the study of Greek literary works and rhetoric in a homily on the psalms for being devoid of anything that would contribute to knowledge of God." ${ }^{30}$ Greek philosophies were only useful in as much as they could be used to communicate the truths of Christianity. For Origen, philosophy was merely a crutch to be used for the true goal of understanding Scripture. This highlights one of Origen's most important characteristics: he placed the knowledge of God above all things. To him, if something did not lead him closer to God, it was not worthy of his note.

Eusebius tells us that Origen also took up study in Hebrew, thinking that it was the best way to enhance his own understanding of Scripture. Some scholars today question whether Origen truly possessed any knowledge of Hebrew. This argument is based on Origen's choices when it came to commentary. When the Hebrew and the Septuagint translation of the Bible seemed to differ, he usually went with the Septuagint. This however is not significant evidence that he lacked knowledge of Hebrew. Crouzel argues that Origen's preference for the Septuagint stemmed from his belief that this text was the one that the apostles had entrusted to the Church. Moreover, he believed that the Holy Spirit had purposefully included passages that were difficult to understand in the translation in order to encourage readers to go beyond the literal meaning and seek the spiritual. ${ }^{31}$

Origen did not only seek to advance his own learning, but he also travelled widely to give lectures. Ancient accounts mention trips to Rome and Athens, among others. One such trip would be the beginnings of his troubles with his local bishop. On a visit to Palestine, he accepted the request of local bishops to give a lecture to the congregation on Scripture. Once Demetrius had heard of this breach of ecclesiastical law, according to which laymen could not preach before bishops, he was livid and demanded the immediate return of 'his' Catechist. ${ }^{32}$ Origen dutifully returned to Alexandria and remained there for the next few years.

\section{The World of Written Word}

While in Alexandria, Origen acquired a student, Ambrose, who followed the Valentinian Gnostic School. Delighted by what he had learned at the hands of Origen, Ambrose converted to orthodoxy and put all of his material wealth and prestige behind Origen, asking him to write a commentary on the Gospel of John. He provided him with "seven stenographers to take his dictation, seven scribes for copping the books, and an unspecified number of young women who could do Calligraphy,"

\footnotetext{
${ }^{29}$ McGukin, The Westminster handbook to Origen, 7.

${ }^{30}$ Heine, Origen: Scholarship in the service of the church, 63.

${ }^{31}$ Crouzel, Origen, 12; McGukin, The Westminster handbook to Origen, 73.

32 McGukin, The Westminster handbook to Origen, 9.
} 
creating a sort of publishing house. ${ }^{33}$ The commentary on John would only be one of Origen's many writings to come. Ambrose's motive for doing this was that the heterodox were producing numerous commentaries on the Gospels, and he believed that if left unchecked, they would sway orthodox Christians with their 'false doctrines. ${ }^{34}$ Although this was a time before Church language had become entrenched, an understanding of orthodoxy and heterodoxy still existed within the Christian community. The orthodox Christians were generally seen as the defenders of the Apostolic tradition, while the heterodox were seen as seekers of knowledge-even if it was not necessarily consistent with the original Christian ideology.

Origen's move into the world of written work and publication brought him into conflict with Demetrius almost immediately. The latter doubted his catechist's orthodoxy. Origen seemed to hold some bizarre views on salvation. Because Eusiebus' account of the proceedings bases Demetrius' objections on Origen's appointment to ecclesiastical rank at the hands of someone other than his own bishop, centuries worth of speculation on Demetrius' motives exist. Some scholars believe that Demetrius had legitimate grievances regarding Origen's orthodoxy and also believe Eusebius purposefully downplays those in order to cast Demetrius as the agitator. ${ }^{35}$ Others attribute jealousy of Origen's fame and a sense of pride at the honor of presiding over a wealthy city such as Alexandria as reasons for Demetrius' disapproval of Origen. ${ }^{36}$ What is more likely is that Demetrius feared Origen's philosophical speculation. Demetrius is accredited with an unwavering dedication to orthodoxy and a crackdown on heresy and Gnosticism in Alexandria. ${ }^{37}$ Demetrius was an uneducated man, and Origen's appropriation of Greek philosophy into Christian teaching would likely have made little sense to him and have appeared dangerously reminiscent of Gnosticism. Origen's popularity and empire-wide fame likely only compounded his fears. He likely thought that the best way to deal with Origen was to prevent him from teaching. Demetrius believed that it would be better if all Christians were content with the existing explanation of Scripture and stopped seeking this fabled 'hidden' knowledge. This, coupled with the fact that Origen did intermittently deviate from the orthodox understanding, made Demetrius very weary of this teacher.

\section{A New Resident at Caesarea}

Eventually, the conflict between Origen and his bishop became so serious that he felt the need to relocate from Alexandria to Caesarea, a place where his talents were appreciated. On his second trip to the city, while still residing in Alexandria, the bishops of the area again asked him to expound on Scripture. This time, to avoid provoking Demetrius' ire, they ordained Origen a priest so that he could speak in front of them. ${ }^{38}$ This had the opposite effect. As angry as Demetrius had been before, this time his fury would cause him to begin a systematic discrediting of Origen's reputation which included publicizing the story of his castration and accusing him of heterodoxy. It was because of this that even Caesarea became suspicious of Origen. During the time of his relocation, Origen was bent on proving the orthodoxy of his doctrines.

He eventually succeeded and assumed the responsibilities of a presbyter in Caesarea. This would constitute the most literary progressive time of Origen's life. Unlike Alexandria, where Gnosticism had taken strong root, Caesarea was a city with a thriving Jewish community and was a center of

\footnotetext{
${ }^{33}$ Heine, Origen: Scholarship in the service of the church, 89-90.

34 Ibid., 91.

35 Ibid., 122.

${ }^{36}$ Chadwick, The Early Church, 109.

37 Atiya, Aziz Suryal, "Demetrius," The Coptic Encyclopedia, vol. 3 (Macmillan: Claremont Graduate University School of Religion, 1991), 2.

38 McGukin, The Westminster handbook to Origen, 15.
} 
Rabbinic study. ${ }^{39}$ Christians in Caesarea would often attend the Jewish services in addition to the Christian ones, a practice Origen discouraged. ${ }^{40}$ The homilies on Jeremiah, which Origen is believed to have delivered to his Caesarean congregations, show much of the frustrations he dealt with in Caesarea. In these homilies, he often refers to Christians who kept old Jewish customs. The concerns and challenges facing Caesareans were very different in comparison to what Origen was accustomed to in Alexandria. Because of this, Origen's focus shifted away from combating Gnostic ideas during his time in Casearea, and instead toward defending the use of the law in the Church, as well as showing how Christians read the law differently from Jews. ${ }^{41}$ He stressed the shortcomings of a literal interpretation of the law, insisting that literal readings made people Jews and not Christians. ${ }^{42}$ According to Heine, he put very high intellectual, moral, and spiritual demands on the Church, and he became frustrated when they did not meet his expectations.

In Alexandria, his primary objective was educating people about the Bible. The people with whom he often dealt with were the educated upper class who wished to make use of his profound knowledge of Scripture. As previously mentioned, Alexandria was a bustling intellectual center where people flocked to obtain and enhance their education. Alexandrian intellectual culture trickled down even to the washer women. Egypt itself had a very religious reputation which extended to the Church in Alexandria. They were often perceived to be the Christians who adhered most strongly to the strict moral principals as a result of their already rigorous attitudes and traditions. ${ }^{43}$ When Origen moved to Caesarea, he left all of that behind for a congregation that was very representative of the cities of the Roman Empire. He now had consistent interactions with individuals who were not necessarily educated, and whose concerns in life were much more practical. Many of these people had no patience for Origen's philosophical wonderings. Still, many enjoyed hearing [his] commentaries, and the more relaxed environment of Caesarea gave him a much greater opportunity to write.

\section{Martyrs and Confessors}

Throughout his time in Caesarea, Origen continued to teach and travel. He came into contact with many notable and powerful figures in the Roman Empire, and his reputation grew in correspondence. This assent upward was put to an abrupt halt when the Emperor Decius succeeded the Emperor Philip. Philip was believed to be sympathetic to the Christians, so Decius, as Philip's enemy, consequently proceeded to persecute the Christian churches. ${ }^{44}$ Eusbieus gives his readers a graphic description of Decius' attack against Origen, which he believed to be particularly fierce.

[...]how the evil demon marshalled all his forces in rivalry against the man, how he led them with every device and power, and singled him out, above all others upon whom he made war at that time, for special attack; the nature and extent of that which he endured for the word of Christ, chains and tortures, punishments inflicted on his body, punishments as he lay in iron and in the recesses of his dungeon; and how, when for many days his feet were stretched four spaces in that instrument of torture, the stocks, he bore with a stout heart threats of fire and everything else that

\footnotetext{
${ }^{39}$ Heine, Origen: Scholarship in the service of the church, 147.

${ }^{40}$ Ibid., 175.

${ }^{41}$ Ibid., 176.

42 Ibid., 174.

43 McGukin, The Westminster handbook to Origen, 39.

44 Eusebius, Ecclesiastical history II, 95.
} 
was inflicted by his enemies; and the kind of issues he had thereof, the judge eagerly striving with all his might on no account put him to death $[. . .]^{45}$

Eusebius carefully noted that the judge allowed for Origen to be tortured to the extreme, but always stopped short of imparting death. This is likely because of Origen's position in the Church. He was known as one of Christianity's greatest teachers. Even Greek philosophers would flock to listen to him. His commentaries on the Bible were plentiful and popular. Decius realized the opportunity that had fallen into his hands. If he could get someone such as Origen to renounce the Christian faith, then he would also do considerable damage to the movement itself. Fortunately for Origen, Decius was assassinated after only two years as emperor. Origen outlived Decius and returned home, only to die of his injuries months later. The crown of martyrdom, which he had sought at sixteen, eluded him again at sixty-nine.

Origen's views on martyrdom had a profound effect on Christianity during his own time, and even today in the Egyptian church, it continues to sway the hearts of many. In his youth, Origen had watched his father become a martyr, and later in life, he watched his own students, one by one, also meet the executioner the same way his father had. As an old man, Origen saw his friend and benefactor, Ambrose, taken and martyred by Roman soldiers. Origen's reaction to each of these traumatic events was the same. He defiantly supported them and encouraged his friends to remain steadfast in the face of torture and death. Because it was such a big part of his life, it must have come as a shock to Origen when he would actually have to defend the legitimacy of martyrdom to his Gnostic contemporaries. Many Gnostics, who saw Christianity as "secret knowledge" could not understand how one could bear "public" witness to it. Others, who tried to avoid persecution by complying to the demands to worship other gods, argued that the name given to God is indifferent. One may still worship the supreme God, but call him Zeus or Zen, Apollo, Artemis, or Demeter. ${ }^{46}$ Origen vehemently rejected this, arguing that names were connected by nature to the object, and insisted that "idolatry was apostasy in persecution."

If Egypt retained anything from Origen's legacy, it would be his attitude toward martyrdom, which remains as widespread among Egyptian Christians today as it was in Origen's day, if not more so. Origen's spirit was one thing that survived through the centuries. When Ambrose was arrested, Origen took the time to compose a letter of encouragement for his friend, "The Exhortation to Martyrdom." Several distinct themes reverberated throughout the letter. He carefully employes the use of Christian language and references to Scripture are strewn throughout. ${ }^{48}$ The strength of the language used to invoke sacrifice for the name of Jesus, as well as on Christ's own sacrifice for mankind, stands out in this work. Later Egyptian martyrdom literature, of which there is no shortage, repeats the same themes even in the present day. "Ya karuuz," one poem popularized by the internet in twenty-first century Egypt, echoes some of the themes present in Origen's letter:

I fear not the cup of death, nor the taste of its juice, for I am the son of the one who,

\footnotetext{
45 Ibid.

${ }^{46}$ Heine, Origen: Scholarship in the service of the church, 168.

${ }^{47}$ Ibid., 165.

${ }^{48}$ Heisey, Origen, the Egyptian, 29.
} 
by death this day cut open the path,

Don't count us as captives,

Don't count these chains, an Ordeal,

Instead, the captive has become

By Jesus, a free captive (captivated by his love)

His blood was shed for my sins,

and I was dressed in his deep love,

for my master has truly risen,

destroying the depths of the dungeon,

Truly he has risen victorious,

having annihilated the first death. ${ }^{49}$

Unlike "The Exhortation to Martyrdom," this Egyptian poem was not written to a specific person. Its goal, however, is the same as Origen's was: to strengthen Christians in the face of persecution and the threat of martyrdom. Even though centuries separate the two pieces of writing, the parallels are striking. The same emphasis on sacrifice exists in both; the numerous scriptural evocations, most especially to the Pauline letters, are present in both. The most striking similarity, however, is not the language, but the defiant spirit found in both. When Origen writes to Ambrose, he tells him to put away everything else and go steadfast into martyrdom. ${ }^{50}$ Death for Christ is accepted not only as a necessity, but a matter of pride. The same energy is conveyed by the introductory lines of the poem, "I fear not the cup of death nor the taste of its juice." Origen's attitude toward martyrdom is an notable part of his legacy that continues to impact people today.

\section{Doctrinal Disputes and Origenism}

After Origen's death, the Christian community found itself in the thick of doctrinal disputes. While there were points that all agreed upon, it was becoming increasingly evident that Christians needed to find a common way of defining the details of their faith. While it was understood that God was One, yet a Trinity at the same time, there was no way to explain satisfactorily what was meant by that. Several competing explanations ran rampant throughout the community. Monarchism for example, held two differing interpretations of the Trinity. The first was that the Father, Son and Holy Spirit are "mere names which do not correspond to any distinctions within the Godhead." 51 The second held that Christ was a holy teacher "fulfilled to a unique degree with the Spirit of God." 52 Everyone knew how opposed Origen had been to the Monarchist view of the Trinity. He had outlined an alternate understanding that stood in strong contrast to Monarchism. Though one of the hottest debates of the era, the doctrine of the Trinity was not the only one in dispute. In an attempt to outline the semantics of the Christian faith, Origen had written a book called On First Principles. In it, he described his understanding of the Trinity, along with several other doctrines. Origen's understanding of Christian doctrine would eventually come to be called Origenism.

Origenism today has specific distinct markers. ${ }^{53}$ The first, and most obvious, is the allegorizing of Scripture. As noted previously, Origen was famous for his allegorization of scripture. It was a style he continually advocated, especially in the later part of his life when his contact with Jewish Rabbis

\footnotetext{
49 "Ya karuuz" poem, http://www.jesus-all-things.com/taraneem.html.

50 Heisey, Origen, the Egyptian, 186.

51 Chadwick, The Early Church, 113.

52 Ibid.

53 Robert L. Fastiggi, “Origen and Origenism," The New Catholic Encyclopedia supplement 2009 (Detroit: Gale/Cengage Learning, 2009).
} 
increased. The second is his understanding of the Trinity, which was actually much more in line with Orthodoxy than Monarchism. He stated that the Father, Son, and Holy Spirit were all distinct beings, within one Godhead. However, he also believed that the three Divine persons were subordinated to one another in some way. ${ }^{54}$ After his death, there was a significant backlash against his views and the Monarchist doctrine gained some popularity until the belief was condemned by the bishop of Alexandria, Dionysius, who had been a student of Origen. ${ }^{55}$ The third and final marker of Origenism was a belief in Universalism and the theory of successive trials. Universalism was a belief that all people will, in the end, be saved from condemnation by the death and resurrection of Christ. ${ }^{56}$ The theory of successive trials, on the other hand, was the idea that one would continue being reborn if they could not succeed in living a righteous life in their previous attempt-an idea almost identical to Eastern notions of reincarnation.

\section{Origen on the Theory of Successive Trials}

This final marker has been throughly examined by scholars, and some have questioned whether Origen really believed the theory of successive trials. It has been argued that there were individuals, specifically a woman close to the papacy named Marcella, who added 'heretical ideas' to the Latin translations of Origen's works. Rufinis, the translator, complained of this. We cannot verify this today, as most of said works have been lost. Scheck however, believes that the excommunication of Origen by the Pope of Rome was more due to Ecclesio-politics than to an actual understanding of Origen's doctrines. ${ }^{57}$

The theory of successive trials on the whole is strikingly similar to Eastern notions of reincarnation. It is difficult to see how Origen could hold a belief in Universalism-the final restoration of all things - as well as a belief in the theory of successive trials when the two are fundamentally at odds with one another. ${ }^{58}$ After all, what is "final" about a "continuous" set of trials? Origen was a man insistent on getting away from the inconsistencies of Gnosticism. The attention to the subtle details which he demonstrates in his works has astounded scholars for centuries. That makes it more unlikely that he would affirm two opposing doctrines and not try to reconcile the two.

Geddes MacGregor is one scholar who was convinced that Origen believed in reincarnation. He asserts that all of Origen's writings which discussed reincarnation were destroyed. Despite his stance however, even he could not deny that there is no extant proof that Origen ever held a favorable opinion of reincarnation. ${ }^{59}$ Since Origen lived and worked in the central areas of Roman Empire, he was primarily influenced by Greek philosophy. Thus, it is not likely that he was very familiar with the Eastern belief regarding reincarnation, but rather with a similar Greek principal called the "transmigration of the soul." The theory of the transmigration of the soul emphasizes the continuity of the soul, implying that it will be reborn again in a different flesh, simply because of its continuity. Even if Origen did know of the Eastern concept, it is likely that he saw Greek philosophy as superior. His readers were also primarily Greek-educated, so discussing the Greek idea of transmigration would 'be more feasible.' We know that Origen outrightly rejected this belief in his

\footnotetext{
${ }^{54}$ Ibid.

${ }^{55}$ Chadwick, The Early Church, 113-4.

56 Origen of Alexandria, On First Principles, I.6.1-3.

${ }^{57}$ Scheck, Thomas P, Commentary on the Epistle to the Romans Books 1-5, (Washington, D.C.:, 2001), 6.

${ }^{58}$ Fastiggi, "Origen and Origenism."

59 Geddes MacGregor, Reincarnation in Christianity (Wheaton, Ill: Theosophical Pub. House., 1978), 58.
} 
commentary on the Gospel of Matthew, which was his final work. ${ }^{60}$ In light of this, it is difficult to attribute to Origen the theory of successive trials.

In this place [when Jesus said Elijah was come and referred to John the Baptist] it does not appear to me that by Elijah the soul is spoken of, lest I fall into the doctrine of transmigration, which is foreign to the Church of God, and not handed down by the apostles, nor anywhere set forth in the scriptures. ${ }^{61}$

\section{Origen's Doctrine of Universalism}

The doctrine of Universalism, on the other hand, appears more rightly attributed to Origen because of references to it in his existing work. It provides us with valuable insight into his character. Origen saw God in a fundamentally Christian way. He was the Almighty, who was constant and unchanging, and who was in complete and total control of every minute aspect of the universe. He had all wisdom, knew all things, and most importantly, cared very much for the fate of mankind. Origen was also a strong believer in free will. He was repulsed by the popular notion that "all events on earth are determined by the planets and stars," and was horrified to find Christians, in addition to non-Christians, believing in astrology. ${ }^{62}$ Origen argued that to believe such a thing was to obliterate free will along with all reward and punishment for human conduct, as well as to annul the message of the Bible and the work of Christ. He also believed that to attribute a person's faith in God, or lack of it, to movement of the stars frees humans of guilt and instead puts the blame on God, which was unacceptable. ${ }^{63}$

Origen's belief in free will is often highlighted with a debate he had with a Gnostic teacher. The Gnostic doctrine of natures, which was the topic of discussion, stated that "all living beings have been given a particular predetermined nature which they cannot change." 64 Such wording may be construed as to also include the Devil, whom they believed that God had created as evil. Origen found this idea unworthy of God, and instead argues that the Devil assumes free will just as humans do, and that God created him the same as he created everything else. It was only by his own free will that he fell. ${ }^{65}$ It was because of this episode that the doctrine of Salvation of the Devil was also attributed to Origen, though he denied believing such a thing.

Origen's problem appeared when he tried to reconcile free will and his view of God. One can only sympathize with his dilemma. How could the Almighty, omniscient and capable of all, fail to save all that he had created? On the other hand, what about people who repeatedly chose to live apart from God? To Origen, suggesting that God would allow certain people to perish was akin to saying that God was either too weak to save them, or that He did not love them enough to do so. Both notions would go against Origen's understanding of God. Since there could be no compromise in God's character, then all must come to Salvation. How did free will fit into such rationale? Origen could not explain this, but surely the alternative was impossible. Thus, the doctrine of Universalism was born. Heine argues that Origen backed away from this belief in his later years. ${ }^{66}$ Once he had spent some time in contact with real congregations and saw first-hand the mess of free will. However, since references to Universalism exist in his later works, it is more likely that Origen felt that he

\footnotetext{
${ }^{60}$ Heine, Origen: Scholarship in the service of the church, 236.

${ }^{61}$ Commentary on Matthew, Book XIII 13:1:46-53.

${ }^{62}$ Heine, Origen: Scholarship in the service of the church, 111.

${ }^{63}$ Ibid.

${ }^{64}$ Ibid., 112.

${ }^{65}$ Ibid., 191.

66 Ibid., 251.
} 
lacked an answer. God still could not be seen as unable or unwilling to save man. Origen placed the attributes of God above all, and was prepared to compromise other understandings so that they could fit with his understanding of God.

\section{Origen's Condemnation}

Origen's condemnation was a thorny affair. He was first condemned in Alexandria by his bishop Demetrius, and this was the cause of his escape to Caesarea. The bishops of Palestine, Arabia, Phenicia, and Archia were the only ones with reservations regarding the condemnation, while Rome consented though it's not known under what conditions. ${ }^{67}$ At the turn of the fourth century, long after his death, Origen's name and legacy came into the spotlight. "The monks of Nitria professed an exaggerated enthusiasm for Origen, whilst the neighboring brethren of Sceta, as a result of an unwarranted reaction and an excessive fear of allegorism," adopted an intense literalism. ${ }^{68}$ Origen's doctrines became the hot topic of the day. Epiphanius, the Bishop of Salamis at the time, put all his efforts into combating the spread of Origenism, while many others opposed him. After an extended debacle, an effort was made to suppress Origenism everywhere.

Quiet reigned about the issue until 514 A.D. when tensions flared up once more. A new charge of Origenism was brought, which resulted in Emperor Justinian's composition of the Liber adversus Origenism, which explained the condemnation of Origen. Justinan ordered the Patriarch Mennas to call together all the bishops in Constantinople, and had them subscribe to the anthemas. Justinian's new edict, which is no longer extant, resulted in the assembling of the fifth Ecumenical Council at Constantinople, in Origen and Origenism were condemned. ${ }^{69}$

\section{Conclusion}

Origen was indeed a controversial character who possessed, and still possesses, a peculiar hold on the hearts of the masses. Perhaps one of the reasons for this is that we know just enough about him. Unlike most of the early fathers, Origen's life story has survived the centuries thanks to Eusebius' favor. Eusebius' story was likely intended to arouse sympathy for Origen. Yet even a critical reading, coupled with Origen's own works, leaves readers with a sympathetic impression of the man. He was presumably talented in interpretation, diligent, industrious, and passionately loyal to his own principals. He was gifted with words, and an excellent orator. His character is also very easy to admire. Origen becomes all the more laudable when one reads about the persecutions he endured, the reasons for which history is sketchy about, though Esubuis attributes it to his ordination at the hands of foreign bishops. Origen is likely such an attractive character because he seems almost like a tragic hero who continues to be wronged, even post-mortum. He seems to have had many enemies, yet the reasons why can only be guessed at. Was Origen simply envied for his brilliance and fame or did he really hold to heterodox ideas? Were his writings sincere, or did he purposefully target Orthodox believers with malicious intent? Eusebius tells the story of the calamities that befell an astute thinker, but leaves out his enemies' motives or simply paints them as vindictive. It is easy to fill in the blanks anyway one wishes. To some, Origen was an evil-intentioned heretic, and to others, a misunderstood, yet righteous man. This only adds to the intrigue that surrounds him.

History does not omit Origen's faults. Even Eusebius could not hide evidence of his self-castration, and some of his own renegade ideas have survived in written form today. Yet the way he made his mistakes only serves to increase his allure. His self-castration may have been a mistake in the eyes of

\footnotetext{
${ }^{67}$ Cyril C. Richardson, “The Condemnation of Origen.” Church History 6 (1937), 55.

${ }^{68}$ Fastiggi, "Origen and Origenism."

${ }^{69}$ Ibid.
} 
the Church. Yet, it was only his insatiable desire to live an uncompromisingly pure life that led him to commit such an error. His theory of universalism was born out of a refusal to attribute to God characteristics unworthy of Him. His mistakes, in other words, were not the results of a lack of information, but rather of an adamant, uncompromisingly loyal spirit. This, taken into account with the fact that Origen lived at a time when Christian doctrine was being pulled in various directions, increases his allure even more.

Finally, Origen's compositions, whether in writing or given in a homily, were exceptional. His attention to detail, insightful conclusions, and gratifying spirituality pulls seekers even today. Even his enemies, such as Epiphanius of Salamis who believed that Origen had adulterated Christian doctrine with Greek philosophy, grudgingly "admitted that there was excellent stuff in his bible commentaries." Modern scholars similarly view him with awe. His commitment to his work, his care for old documents, and his method for the critical analysis of ancient texts are seen as reasons to respect him. Ultimately, Origen's works satisfy spiritual seekers and impress cynical scholars. It was inevitable that he would become one of history's most relatable figures.

${ }^{70}$ Chadwick, The Early Church, 113. 


\section{Bibliography}

\section{Primary sources}

Origen, and John Patrick. 1981. Origen's Commentary on the Gospel of Matthew. New York: Scribner.

Origen, Paul Koetschau, and G. W. Butterworth. 1966. On first principles; being Koetschau's text of the De principiis. New York: Harper \& Row

Origen, and Thomas P. Scheck. 2001. Commentary on the Epistle to the Romans. Books 1-5. Washington, D.C.: Catholic University of America Press.

AlKaruuz. "Ya Karuuz" poem, http://www.jesus-all-things.com/taraneem.html

\section{Secondary sources}

Atiya, Aziz Suryal, 1898-1988 (editor-in-chief), and Atiya, Aziz Suryal, 1898-1988. 1991. Demetrius. Macmillan. http://ccdl.libraries.claremont.edu/u?/cce,726.

Chadwick, Henry. 1967. The early church. London: Penguin Books.

Cribiore, Raffaella. 2005. Gymnastics of the mind Greek education in Hellenistic and Roman Egypt. History E-Book Project. Princeton, N.J.: Princeton University Press. http://hdl.handle.net/2027/heb.02272.

Crouzel, Henri. 1989. Origen. Edinburgh: T. \& T. Clark.

Eusebius, Kirsopp Lake, John Ernest Leonard Oulton, and Hugh Jackson Lawlor. 1926. The ecclesiastical history. London: W. Heinemann.

Fastiggi, Robert L. 2009. New Catholic encyclopedia supplement 2009. Detroit, Mich: Gale/Cengage Learning. http://galenet.galegroup.com/servlet/eBooks?ste=22\&docNum=CX3005499999.

Heine, Ronald E. 2010. Origen: scholarship in the service of the Church. Oxford: Oxford University Press.

Heisey, Nancy R., Origen, the Egyptian : a literary and historical consideration of the Egyptian background in Origen's writings on martyrdom, (Nairobi, Kenya. Paulines Publications Africa, 2000

MacGregor, Geddes. 1978. Reincarnation in Christianity: a new vision of the role of rebirth in Christian thought. Wheaton, Ill: Theosophical Pub. House.

McGuckin, John Anthony. 2004. The Westminster handbook to Origen. Louisville, Ky: Westminster John Knox Press.

Payne, Robert. 1958. The holy fire; the story of the Fathers of the Eastern Church. London: Skeffington.

Richardson, Cyril C. 1937. "The Condemnation of Origen". Church History. 6 (1): 50-64.

Trigg, Joseph Wilson, and Origen. 1998. Origen. London: Routledge. 